German Cancer Research Center, Institute for Immunology and Genetics, Heidelberg, Federal Republic of Germany

\title{
Biological Aspects of Tumor Necrosis Factor
}

\author{
DANIELA N. MÄNNEL
}

\begin{abstract}
Tumor necrosis factor (TNF) has been determined as an endogenous mediator for endotoxin-induced tumor necrosis. This macrophage product has been biochemically characterized and its protein structure defined by molecular cloning of the TNF gene. Experiments with antibodies to TNF demonstrated that TNF acts as an effector molecule of activated cytotoxic macrophages involved in tumor destruction.

Purified TNF has been shown to exert direct necrotic activity against tumors in vivo. In addition, a number of similar effects in vivo and in vitro of TNF, endotoxin, and interleukin 1 (IL 1) have been observed. For example, in vivo the thermoregulatory activity of TNF is similar to IL 1. Since TNF was found to mediate other effects of endotoxin in modulating immune responses in addition to the tumor necrotic activity, it can be considered a true immunoregulator produced by macrophages after endotoxin stimulation.
\end{abstract}

\section{Introduction}

The endotoxin-induced tumor necrosis phenomenon has been the subject of intensive clinical, biological, and biochemical research for many decades $(1,2)$. Numerous attempts have been undertaken to separate the beneficial tumor cytotoxic effects of endotoxin from the harmful pathophysiological endotoxic effects. Elucidation of the lipid A structure as the endotoxic principle of bacterial lipopolysaccharide (LPS) revealed the chemical structure responsible for the tumor necrosis eliciting activity $(3,4)$. However, due to the work of OLD et al. (5), it became obvious that the LPS-induced tumor necrosis was not a direct effect of LPS or lipid A on the tumor mass but rather an indirect phenomenon. An endogenous mediator, termed tumor necrosis factor (TNF), was elicited as a second messenger by LPS injection of animals with an activated reticular endothelial system.

Characterization of the producer cells for TNF, requirements for TNF production and molecular cloning of the TNF genes in different species made clear that activated macrophages are a source for TNF $(6,7)$. The recombinant form of the TNF molecule was found as a $17,000 \mathrm{D}$ protein in the case of human TNF (8). The amino acid sequence of the human TNF

\footnotetext{
Abbreviations: $B C G=$ Mycobacterium bovis; IFN = interferon; IL $1=$ interleukin 1; LPS $=$ lipopolysaccharide; $T N F=$ tumor necrosis factor.
} 
showed about $80 \%$ homology with murine TNF. In contrast to the human TNF, murine TNF contained one potential N-glycosylation site (9). The activity of TNF seemed not to be species-specific.

Besides the tumor necrotic activity in vivo of TNF, a rather selective tumor cytotoxic activity of TNF has been observed and used as a sensitive in vitro test system. With the availability of purified and/or recombinant TNF, a number of biological TNF activities have been determined. Even though TNF was characterized as the endogenous mediator of endotoxininduced tumor necrosis, it has not been possible to separate the beneficial tumor necrotic effect as a distinct quality from all the other endotoxic activities.

\section{Materials and Methods}

Mice

Male and female $\mathrm{C} 3 \mathrm{H} / \mathrm{He}$ mice, 6 to 10 weeks of age, were obtained from Charles River Wiga, Sulzfeld, F.R.G., and $\mathrm{C} 3 \mathrm{H} / \mathrm{HeJ}$ mice were purchased from Jackson Laboratories, Bar Harbor, ME, U.S.A.

\section{Reagents}

Recombinant human TNF was generously supplied by BASF, Ludwigshafen, F.R.G., and recombinant IFN- $\gamma$ (produced by Genetech, Inc.) by Boehringer Ingelheim. Mycobacterium bovis, strain BCG (Phipps substrain, TCM 1029, Trudeau Mycobacterial Collection, Saranac Lake, NY, U.S.A.), pyran copolymer (National Cancer Institute, Bethesda, MD, U.S.A.), Corynebacterium parvum (Wellcome Research Laboratories, Beckenham, England) and latex beads (1- $\mu \mathrm{m}$ polystyrene beads, Dow Chemical Co., Midland, MI, U.S.A.) were injected intraperitoneally to activate macrophages.

\section{Assays for TNF}

TNF samples were cultured with $4 \times 10^{3}\left({ }^{3} \mathrm{H}\right)$ TdR-prelabeled L929 tumor cells for $48 \mathrm{~h}$ in a culture volume of $0.2 \mathrm{ml}$. Cytotoxicity was estimated by measuring release of $\left({ }^{3} \mathrm{H}\right) \mathrm{TdR}$ from tumor cells and expressed as \% release of total incorporated counts. In another test system, TNF samples were cultured with $2 \times 10^{4} \mathrm{~L} 929$ tumor cells for $24 \mathrm{~h}$ in $0.2 \mathrm{ml}$ cultures in the presence of actinomycin $\mathrm{D}(2 \mu \mathrm{g} / \mathrm{ml})$, and viable cells were determined by staining with crystal violet.

\section{Macrophage cytotoxicity assay}

$\left({ }^{3} \mathrm{H}\right) \mathrm{TdR}$-prelabeled tumor cells $\left(6 \times 10^{3} \mathrm{~L} 929\right.$ or 1023 fibrosarcoma cells $)$ were cultured together with $1.2 \times 10^{5}$ peritoneal exudate cells in $0.2 \mathrm{ml}$ cultures for $48 \mathrm{~h}$. Cytotoxicity was estimated by measuring release of $\left({ }^{3} \mathrm{H}\right) \mathrm{TdR}$ from tumor cells and expressed as \% release of total incorporated counts.

\section{Blood parameters}

Plasma glucose levels were determined with a Gluco-Quant glucose kit, and plasma lactate levels were measured with a Monotest-Lactat kit (both from Boehringer, Mannheim, F.R.G.). 


\section{Results}

TNF as a tumor cytotoxic effector molecule of activated macrophages

The mechanism of tumor cell destruction by activated macrophages is not well understood. Cell contact of macrophages with tumor cells seemed to be required, and no soluble cytotoxic activity was measurable in conventional macrophage cytotoxicity assays. However, when macrophages are activated they become extremely sensitive to lipid A stimulation (10). Therefore, we investigated the production of TNF by murine macrophages upon LPS exposure and compared the TNF-producing ability with the tumoricidal capacity of these macrophages. Release of TNF from macrophages upon LPS stimulation was only observed when the macrophages had been appropriately activated before. The activation correlated with the potential of the macrophages for tumor cytotoxicity (Table 1). Thus, only tumor cytotoxic macrophages were able to secrete TNF into the medium as a response to LPS. This indicated a possible role of TNF in macrophage tumor destruction.

Rabbit antibodies directed against semipurified murine TNF have been generated and had good TNF-neutralizing activity (11). These antibodies were also capable of inhibiting macrophage tumor cytotoxicity (Table 2), even though no soluble TNF was found in the supernatants of these cytotoxic macrophages in the absence of added LPS. Culture morphology demonstrated an even more striking inhibition of macrophage tumor cell destruction by the TNF antibodies. Cultures of activated macrophages and tumor cells showed a strong cytopathic effect, whereas in identical cultures

Table 1. Correlation between macrophage tumoricidal activity and release of TNF

\begin{tabular}{lccc}
\hline $\begin{array}{l}\text { Macrophages from } \\
\text { mice treated with }\end{array}$ & \multicolumn{2}{c}{$\begin{array}{l}\text { Macrophage tumoricidal } \\
\text { activity }^{\mathrm{b}}(\%)\end{array}$} & \multicolumn{2}{l}{$\begin{array}{l}\text { Release of } \text { TNF }^{\mathrm{c}} \\
\text { (\% cytotoxic activity) }\end{array}$} \\
\hline & & - LPS & +LPS \\
\hline BCG & 26 & 11 & 33 \\
Pyran & 27 & 15 & 38 \\
C. parvum & 23 & 13 & 39 \\
PBS & 9 & 8 & 11 \\
Starch & 7 & 8 & 8 \\
Latex & 9 & 8 & 9 \\
\hline
\end{tabular}

${ }^{2}$ Adherent peritoneal exudate cells were used from mice treated i.p. with $2 \times 10^{6}$ viable BCG, $500 \mu \mathrm{g}$ of pyran, $1.4 \mathrm{mg}$ of C. parvum, $2 \%$ starch in water, latex beads 7 days previously or with PBS 1 day previously.

${ }^{b}$ Macrophage tumoricidal activity (released $\left({ }^{3} \mathrm{H}\right) \mathrm{TdR}$ ) was estimated after $48 \mathrm{~h}$ of coculture with $\left({ }^{3} \mathrm{H}\right) \mathrm{TdR}$ prelabeled tumor cells and expressed as a percentage of total incorporated label.

${ }^{\mathrm{c}}$ For release of TNF the cytotoxic activity of $2 \mathrm{~h}$ supernatants was tested on prelabeled tumor cells as in ${ }^{b}$. 
Table 2. Inhibition of macrophage cytotoxicity by rabbit IgG against TNF

\begin{tabular}{llc}
\hline Stimulus & \multicolumn{2}{c}{ Cytotoxicity $^{2}(\%)$} \\
\cline { 2 - 3 } & Control & anti-TNF \\
\hline BCG & 89 & 40 \\
Pyran & 86 & 47 \\
C. parvum & 90 & 64 \\
\hline
\end{tabular}

${ }^{a}$ Adherent peritoneal exudate cells from mice treated as indicated in the footnote to Table 1 were used. Tumoricidal activity was determined as in Table 1.

but in the presence of anti-TNF the tumor cell density was as high as in the presence of non-activated macrophages. These results not only suggested participation of TNF in macrophage tumor cytotoxicity, but they also implied that this had to occur in a short-range or even membrane-bound fashion.

\section{TNF as mediator of endotoxin effects}

With the availability of purified recombinant TNF, in vivo effects after application of relatively large quantities of this mediator could be studied. Intravenous injection of TNF $(3-4 \mathrm{mg} / \mathrm{kg}$ ) into endotoxin-sensitive $\mathrm{C} 3 \mathrm{H} /$ $\mathrm{He}$ or endotoxin low responder $\mathrm{C} 3 \mathrm{H} / \mathrm{HeJ}$ mice induced a dramatic impairment of well-being of the animals of both strains within $30 \mathrm{~min}$. Hunched back, ruffled fur and diarrhea were the immediate, obvious symptoms. The body temperature of these animals dropped from normal $38^{\circ} \mathrm{C}$ to $30^{\circ} \mathrm{C}$ and below within $5 \mathrm{~h}$ after intravenous TNF application, and some animals died. The time course of decrease of the temperature paralleled the temperature decrease induced by LPS in endotoxin-sensitive $\mathrm{C} 3 \mathrm{H} / \mathrm{He}$ mice (12) (Table 3). However, this effect was not due to endotoxin contamination of the TNF preparation, since this temperature decrease was also observed in the endotoxin low-responder mouse strain.

Table 3. Body temperature changes in mice after TNF or LPS injection

\begin{tabular}{lccccc}
\hline Stimulus & \multicolumn{5}{c}{$\begin{array}{c}\text { Temperature }\left({ }^{\circ} \mathrm{C}\right)^{2} \\
\text { hours post injection }\end{array}$} \\
\cline { 2 - 6 } & 0 & 3 & 6 & 24 & 48 \\
\hline TNF & 38.1 & 30.3 & 29.5 & 34.7 & 35.2 \\
& & $(-7.8)$ & $(-8.6)$ & $(-3.4)$ & $(-2.9)$ \\
LPS & 37.4 & 33.4 & 32.9 & 36.0 & 35.5 \\
& & $(-4.0)$ & $(-4.5)$ & $(-1.4)$ & $(-1.9)$
\end{tabular}

\footnotetext{
${ }^{a}$ Rectal temperatures of C3H/He mice after i.v. injection of TNF $(100 \mu \mathrm{g})$ or LPS $(200 \mu \mathrm{g})$
} were measured. Numbers in parentheses indicate the temperature change. 
Changes of blood and plasma parameters that are typical for endotoxin were observed after TNF application $(13,14)$. Hematocrit levels were significantly increased after $30 \mathrm{~min}$, plasma lactate levels were also increased after $6 \mathrm{~h}$, and plasma glucose levels decreased after $6 \mathrm{~h}$. These data indicated that TNF mediated the pathophysiological effects of endotoxin. This observation is supported by the data of BEUTLER et al. (15), which demonstrated that antibodies to cachectin (which is probably identical with TNF (16)) protected mice from the lethal effects of endotoxin.

\section{TNF as immunomodulator}

Besides the well-known effect of induction of tumor necrosis and in vitro tumor cytotoxicity by TNF, a number of other biological effects on different cell types have been published. Collagenase and prostaglandin $E_{2}$ production by human synovial cells and dermal fibroblasts (17), activation of polymorphonuclear neutrophil function (18), enhancement of surface expression of class I major histocompatibility complex antigens in vascular endothelial cells and dermal fibroblasts (19), stimulation of neutrophil adherence to umbilical vein endothelium (20), stimulation of bone resorption and inhibition of bone formation (21) are only some of these TNF activities. From observations in a number of different laboratories, it became obvious that TNF exhibits an even greater variety of effects.

Synergistic action of TNF and interferon- $\gamma($ IFN- $\gamma$ ) in tumor cytotoxic activity has been documented with a number of different target cells (22). Table 4 demonstrates the increased TNF sensitivity of human HeLa cells and mouse L929 fibrosarcoma cells when pretreated with IFN- $\gamma$. In addition, the production of TNF is enhanced by IFN- $\gamma$ (23). Taken together, these effects demonstrate an effective amplification mechanism for TNF function by IFN- $\gamma$.

TNF itself was also able to regulate the sensitivity of tumor cells to the cytotoxic effect of TNF (Table 5). Higher concentrations of TNF were required to induce $50 \%$ reduction in cell viability when the sensitive L929 cells had been exposed to TNF previously. Also, this protective effect was up to a certain concentration dose dependent. There were two likely

Table 4. Influence of IFN- $\gamma$ pretreatment on the TNF-sensitivity of tumor cells in vitro

\begin{tabular}{lll}
\hline IFN- $\gamma(\mathrm{U} / \mathrm{ml})$ & \multicolumn{2}{c}{$50 \%$ survival $^{2}(\mathrm{ng} \mathrm{TNF} / \mathrm{ml})$} \\
\cline { 2 - 3 } & HeLa & L929 \\
\hline 0 & 1.5 & 0.5 \\
10 & n.d. & 0.125 \\
100 & 0.15 & 0.125 \\
\hline
\end{tabular}

${ }^{a} \mathrm{HeLa}$ or $\mathrm{L} 929$ cells were cultured for $16 \mathrm{~h}$ in different concentrations of recombinant human or murine IFN, respectively. $50 \%$ survival of the cells was determined by $24 \mathrm{~h}$ exposure to different concentrations of recombinant TNF in the presence of actinomycin D. 
Table 5. Influence of TNF-pretreatment on the sensitivity of tumor cells

\begin{tabular}{ll}
\hline $\mathrm{TNF}(\mathrm{ng} / \mathrm{ml})$ & $\begin{array}{l}50 \% \text { survival }^{2} \\
\text { (ng TNF/ml) }\end{array}$ \\
\hline 0 & 0.3 \\
1 & 2.5 \\
10 & 5.0 \\
\hline
\end{tabular}

${ }^{a}$ L929 cells were cultured for $16 \mathrm{~h}$ in different concentrations of recombinant TNF. $50 \%$ survival of the cells was determined by 24 h exposure to different concentrations of TNF in the presence of actinomycin D.

explanations for these observations. One could be the selective killing of the most sensitive cells by the pretreatment, leaving the least sensitive cells behind. The second possibility is that TNF induces a protective state in the cells. A similar self-resistance-induction has already been described for lymphotoxin (24). These observations indicate that the cytotoxic effect of TNF can be regulated by IFN- $\gamma$ and TNF. It remains to be tested whether other TNF activities such as prostaglandin-production, which can regulate immune functions, undergo similar regulation.

\section{Discussion}

Lipid A is the structure responsible for the beneficial and harmful biological properties of bacterial endotoxin (3). Macrophages are exquisite responder cells to lipid $\mathrm{A}$ and react even more strongly when they are in an activated stage (10). Therefore, the idea has developed that endotoxin may cause its pathophysiological effects through interaction with this cell type and eventually via macrophage-derived mediators such as TNF and IL 1. The array of functions of TNF and IL 1 seems to be very similar (with the exception of the effects of IL 1 on T cells). A number of endotoxic effects can be induced with pure preparations of IL 1 or TNF. A clear picture of the molecular mechanisms underlying the mediation of endotoxin effects will probably emerge from ongoing studies with these mediators.

\section{References}

1. Nauts, H. C., G. A. Fowler, and F. H. BogatKo. 1953. A review of the influence of bacterial infection and of bacterial products (Coley's toxins) on malignant tumors in man. Acta Med. Scand. 45, suppl. no. 276.

2. BALDWIN, R. W., and V. S. BYERS. 1979. Immuno-regulation by bacterial organisms and their role in the immuno-therapy of cancer. Springer Semin. Immunopathol. 2: 79.

3. RieTsChel, E. Th., H. MAYeR, H.-W. WOllenWeber, U. ZäHRINGER, O. LÜDERITZ, O. WESTPHAL, and H. BRADE. 1984. Bacterial lipopolysaccharides and their lipid A compo- 
nent in «Bacterial Endotoxin» (J. Y. Homma, S. KANEGASAKI, O. LÜDERITZ, T. SHIBA, and O. WeSTPHAL, eds.), Verlag Chemie, pp. 11-22.

4. MänNel, D. N., D. L. Rosenstreich, and S. E. Mergenhagen. 1979. Mechanism of lipopolysaccharide-induced tumor necrosis: requirement for lipopolysaccharide-sensitive lymphoreticular cells. Inf. Immun. 24: 573.

5. Carswell, E. A., L. J. Old, R. L. Kassel, S. Green, N. Fiore, and B. Williamson. 1975. An endotoxin-induced serum factor that causes necrosis of tumors. Proc. Natl. Acad. Sci U.S.A. 72: 3666.

6. Matthews, N. 1978. Tumor necrosis factor from the rabbit. II. Production by monocytes. Brit. J. Cancer 38: 310.

7. MänNel, D. N., R. N. MoORE, and S. E. Mergenhagen. 1980. Macrophages as a source of tumoricidal activity (tumor necrotizing factor). Inf. Immun. 30: 523.

8. Pennica, D., G. E. Nedwin, J. S. Hayflick, P. H. Seeburg, R. Derynck, M. A. Palladino, W. J. Kohr, B. B. Aggarwal, and D. V. Goeddel. 1984. Human tumor necrosis factor: precursor structure, expression and homology to lymphotoxin. Nature 312: 724.

9. Marmenout, A., L. Fransen, J. van der Heyden, R. Tizard, E. Kawashima, A. Shaw, M.-J. Johnson, D. Semon, R. MÜller, M.-R. RuYsschaert, A. van Vliet, and W. FIERS. 1985. Molecular cloning and expression of human tumor necrosis factor and comparison with mouse tumor necrosis factor. Eur. J. Biochem. 152: 515.

10. Peavy, D. L., R. E. Baughn, and D. M. Musher. 1979. Effects of BCG infection on the susceptibility of mouse macrophages to endotoxin. Inf. Immun. 24: 59.

11. MÄNNEL, D. N., W. FALK, and M. MeLTZER. 1981. Inhibition of nonspecific tumoricidal activity by activated macrophages with antiserum against a soluble cytotoxic factor. Inf. Immun. 33: 156.

12. Prashker, D., and A. C. Wardlaw. 1971. Temperature responses of mice to Escherichia Coli endotoxin. Br. J. Exp. Pathol. 52: 36.

13. LANG, C. H., G. J. BAgBY, A. Nowotny, and J. J. SPITZER. 1985. Effects of toxic and nontoxic endotoxin derivatives on glucose kinetics. Circulatory Shock 17: 301.

14. Sakaguchi, O., S. SAKaguchi, and N. TsunOda. 1979. Changes in the activities of enzymes, especially lactate dehydrogenase, in endotoxin-poisoned mice. Microbiol. Immunol. 23: 605.

15. Beutler, B., I. W. Milsark, and A. C. Cerami. 1985. Passive immunization against cachectin/tumor necrosis factor protects mice from lethal effects of endotoxin. Science 229: 869 .

16. Beutler, B., D. Greenwald, J. D. Hulmes, M. Chang, Y.-C. E. Pan, J. Mathison, R. UlevitCH, and A. CERAMI. 1985. Identity of tumor necrosis factor and the macrophagesecreted factor cachectin. Nature 316: 552.

17. Dayer, J.-M., B. Beutler, and A. Cerami. 1985. Cachectin/tumor necrosis factor stimulates collagenase and prostaglandin $\mathrm{E}_{2}$ production by human synovial cells and dermal fibroblasts. J. Exp. Med. 162: 2163.

18. Shalaby, M. R., B. B. Aggarwal, E. Rinderknecht, L. P. Svedersky, B. S. Finkel, and M. A. PALladino. 1985. Activation of human polymorphonuclear neutrophil functions by interferon- $\gamma$ and tumor necrosis factors. J. Immunol. 135: 2069.

19. Collins, T., L. A. Lapierre, W. Fiers, J. L. Strominger, and J. S. Pober. 1986. Recombinant human tumor necrosis factor increases mRNA levels and surface expression of HLA-A,B antigens in vascular endothelial cells and dermal fibroblasts in vitro. Proc. Natl. Acad. Sci. U.S.A. 83: 446.

20. Gamble, J. R., J. M. Harlan, S. J. Klebanoff, and M. A. Vadas. 1985. Stimulation of the adherence of neutrophils to umbilical vein endothelium by human recombinant tumor necrosis factor. Proc. Natl. Acad. Sci. U.S.A. 82: 8667.

21. Bertolini, D. R., G. E. Nedwin, T. S. Bringman, D. D. Smith, and G. R. Mundy. 1986. Stimulation of bone resorption and inhibition of bone formation in vitro by human tumor necrosis factors. Nature 319: 516.

22. Sugarman, B. J., B. B. Aggarwal, P. E. Hass, I. S. Figari, M. A. Palladino, and H. 
M. SHEPARD. 1985. Recombinant human tumor necrosis factor- $\alpha$ : Effect on proliferation of normal and transformed cells in vitro. Science 230: 943.

23. Nedwin, G. E., L. P. Svedersky, T. S. Bringman, M. A. Palladino, D. V. Goeddel. 1985. Effect of interleukin 2, interferon- $\gamma$, and mitogens on the production of tumor necrosis factors $\alpha$ and $\beta$. J. Immunol. 135: 2492.

24. WALLACH, D. 1984. Preparations of lymphotoxin induce resistance to their own cytotoxic effect. J. Immunol. 132: 2464.

Dr. D. N. MÄNNEL, Deutsches Krebsforschungszentrum, Institut für Immunologie und Genetik, Im Neuenheimer Feld 280, D-6900 Heidelberg, Federal Republic of Germany 